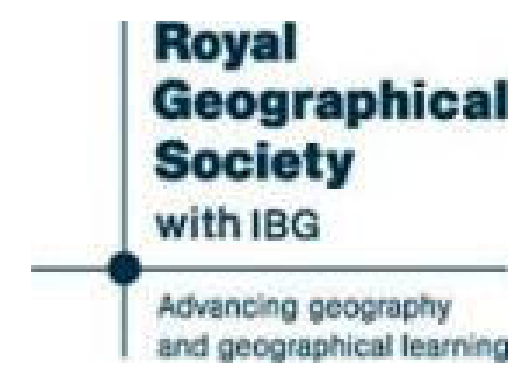

\title{
Early Travels
}

Ibn Gubayr (Ibn Giobeir), Viaggio in Ispagna, Sicilia, Siria... Mesopotamia, Arabia, Egitto; The Travels of Ibn Jubayr by William Wright; M. J. de Goeje

Review by: C. R. B.

The Geographical Journal, Vol. 31, No. 4 (Apr., 1908), p. 436

Published by: The Royal Geographical Society (with the Institute of British Geographers)

Stable URL: http://www.jstor.org/stable/1777858

Accessed: 18/01/2015 13:55

Your use of the JSTOR archive indicates your acceptance of the Terms \& Conditions of Use, available at

http://www.jstor.org/page/info/about/policies/terms.jsp

JSTOR is a not-for-profit service that helps scholars, researchers, and students discover, use, and build upon a wide range of content in a trusted digital archive. We use information technology and tools to increase productivity and facilitate new forms of scholarship. For more information about JSTOR, please contact support@jstor.org. 


\section{Early Travels.}

' Ibn Gubayr (Ibn Giobeir), Viaggio in Ispagna, Sicilia, Siria . . . Mesopotamia, Arabia, Egitto.' Prima traduzione, fatta sull' originale Arabo de Celestino Schiaparelli. Rome. 1906 : Pp. xxvii., 412.

'The Travels of Ibn Jubayr,' edited . . . by William Wright. Second edition, revised by M. J. de Goeje. Leyden : Brill. 1907.

The Arabic text of lbn Jubayr's traveis was ably edited by W. Wright, with the aid of Prof. Dozy (Leyden, 1852); his account of Sicily was edited and translated, with most valuable notes, by M. Amari (Paris, 1846); his description of Syria and Egypt is in great part reproduced, the Arabic text being here also accompanied with a French version, in the 'Recueil des Historiens des Croisades, Historiens Orientaux,' vol. 3 (Paris, 1884); and smaller sections have been dealt with in other works, such as E. Wiedemann's "Beiträge zur Geschichte der Naturwissenschaften" (in Sitzungsb. d. phys.-med. Sozietät in Erlangen, 1905); but Schiaparelli's version of the complete voyages of this great Spanish Moslem renders a great service to all scholars and historians, especially to those unacquainted or but moderately acquainted with Ibn Jubayr's mother-tongue. A valuable introduction (pp. vii.-xxii.) is followed by a useful summary of the route of our traveller, who, starting from Granada on February 4, 1183, returned to Granada on April 25, 1185. The translation itself, occupying 348 pages, is illustrated by serviceable notes, all too brief (pp. 351-68); good indexes of persons and places conclude the work. Among the most noteworthy sections of this Viaggio are (1) those which treat of Moslem Spain, the islands of the Greek archipelago, Crete, Sicily, Sardinia, and the Balearics (pp. 3-8, 310-348); (2) the Mesopotamian sections, especially the description of Baghdad (pp. 198-237, etc.); and (3) the Meccan and Damascene (pp. 53-150, etc., 251-293). Ibn Jubayr was endowed with exceptional qualifications as an observer and historian, and no serious student of the twelfth century can safely neglect him. It is regrettable that no map accompanies this issue.

In 1907 the Trustees of the E.J. W. Gibb Memorial re-issued Wright's text, revised by Prof. de Goeje, with Wright's original preface and notes, and some additions by the reviser. "But a comparison of my edition with the former" (Wright's original) "will show," says de Goeje, "that I had very little to change." It is interesting to know that Robertson Smith intended at one time to have undertaken this revision now carried through by de Goeje. $\quad$ C. R. B.

\section{Texт-Books.}

'A Scientific Geography.' By Ellis W. Heaton, B.sc., F.G.s. London : Ralph Holland \& Co. 1906. Book II. The British Isles. Book IV. North America. Book V. Africa. Maps and Diagrams. Price 1s. 6d. net each.

'Mathematical Geography.' By Willis E. Johnson, Pн.B. Pp. 322. New York : American Book Co. Price $\$ 1.00$.

'A Rational Geography.' In three parts. Part I. (195 pp.) Climate; the British Isles; Europe. By Ernest Young, B.sc. London: George Philip \& Son. 1907. Price 18. 6d. each.

$\mathrm{Mr}$. Heaton's preface states that his books are for students who intend taking the subject for Matriculation, Preliminary Certificate, or Certificate Examinations. Each consists of Part I., dealing with general considerations ; and Part II., sections "each giving all the materials required for a sketch-map such as examiners ask for." The aim of the author is fairly well fulfilled. But, apart from the geological treatment in Parts I. of each, which is in the main good and commendable, the humanistic geographical concepts are wanting, and hence Parts II. have little to recommend them from that point of view. The collection of facts will go far 